\title{
害展 望言
}

\section{学術会議の戦国時代に対処して}

長

哲 郎

Tetsuo OSA

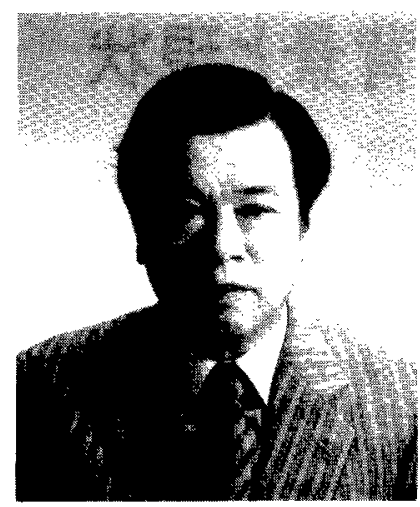

展望の執筆にあたり，筆者が常々考えている学術分野の私見を述 べたかったのですが, 本会の発展のために果たすべき会誌の役割の 重要性を痛感し，あえて編集委員会の努力を紹介させていただきま す、会員各位のご忠言をはじめとする種々の忌憚ないご意見を寄せ ていただくことをまず切望します．この場に相応しくありません が，編集委員会としては，1）質の高い一時情報の豊富な揭載,

2) 揭載分野の搪大，3）本会事業の積極的紹介，4）毎月 5 日発 行の実現一これらの多くは高村 勉前編集委員長の方針でもありま したがーに努力致す所存です。

本誌は電気化学および工業物理化学の分野の論文誌であるととも に, この分野の新しい動向, 会員個人または本会諸事業の活動を紹 介する機関誌の役割を果たしています，学協会の国際協力，学際交 流，産学協同の傾向を反映した諸活動の充実を本会に要望しますが，編集委員会としては外国との雑誌 の交換ないしは寄贈を積極的に行ない，本会の活動の一助としたいと考えます.

本会の諸事業, たとえば年 2 回の大会, 支部, 専門委員会, 研究懇談会, 研究会などにおける会員各 位の活発な活動についてはかねが敉敬しておりますが，その成果の本誌への取り上げが不十分に感じ ます. 大会での研究発表に関しても, 講演申込の際に本誌への投稿の意志確認, 大会終了後関心を呼ん だ講演に対する積極的投稿勧誘などの努力は, 質の向上，分野の拡大に効果があると考えます．もちろ ん著者はサーキュレーションのよりよい，また評価の高い学術誌に投稿しようとするのは自然な成り行 きであり，本誌がそれに報いるべき地道な努力を重ねることが必須であります．近時の学術団体の增加 （日本学術会議の調查では1976〜1986年に約250の団体が新設されたという), 既存学術団体や出版社に よる新分野の学術誌の相次ぐ刊行は, 学術誌の戦国時代の様相を呈しており, 伝統のある本誌といえど も危機感を賞えます。，バイオ技術，電子デバイス，材料，エネルギーなぞ今後発展が予想される分野の 研究論文, 解説論文の投稿勧誘や依頼を積極的に行ない, 魅力ある雑誌としてこの危機を乗り越元発展 させねばなりません。

解説特集, 入門・湘定法, 電気化学のあゆ, 各種の読物は, 会員への学術, コミュニケーションな どの情報提供に役立つものと確信しますが, 通勤途中でも気楽に読める雑誌である必要があります。こ の点からは論文誌之機関誌は別であることが好ましいわけですが, 本会の事情から当面実現は不可能で しょう. A 4 版の学術誌への移行の一般的傾向の中で, 現状のB 5 版を続ける意義は, 本誌の伝統と, 読みやすく会員に愛される学術誌であることを願ってのことです.

いままでの本誌編集担当の方々のご努力を顧りみず勝手な雑言を記しましたが，本誌が今日有るのも 諸先輩の賜であるのは論を俟ちません。

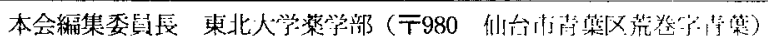

